\title{
Open-air rock-art, territories and modes of exploitation during the Upper Palaeolithic in the Côa Valley (Portugal)
}

\author{
Thierry Aubry, Xavier Mangado Llach, Jorge David Sampaio \\ \& FARID SELLAMI*
}

A study of the differential preservation of the famous Côa engravings, in the light of the site of Fariseu, place the distribution of the art in a chronological setting, which is in turn placed within the context of lithic raw material procurement.

Key-words: rock art, Cô Valley, Upper Palacolithic, differential preservation, climate, resourre exploitation

\section{The natural environment}

The Côa River is a left-bank tributary of the Douro, the major watercourse of the north central Iberian cordillera (FIGURE 1) which crosses Iberia from east to west rising to $2500 \mathrm{~m}$. Tectonics controlled and facilitated Quaternary downcutting south-north into the Pliocene planation surface known as the Mesetam, reaching about $400 \mathrm{~m}$ at the confluence with the Douro. The $120-\mathrm{km}$ long river basin comprises two different geological sectors. The first, from source to within $17 \mathrm{~km}$ of the confluence with the Douro, is through petrographically diverse granites. The second, wider, section grades to a meandering pattern through pre-Ordovician metamorphic rocks. The basin extends over $2419 \mathrm{sq}$. km (FIGURE 1). Temperature records at its midpoint (1960-1970 - Figueira de Castelo Rodrigo station) (FIGURE 2) indicate a mean annual temperature of $11.2^{\circ} \mathrm{C}$ and a wide annual range of $16 \cdot 2^{\circ} \mathrm{C}$. The lowest (December-March) are below $5^{\circ} \mathrm{C}$; the highest above $35^{\circ} \mathrm{C}$ (July-August). Precipitation (mainly rainfall), is concentrated in autumn, winter and, to a lesser degree, spring (FIGURE 3), Annual mean values are less than $1600 \mathrm{~mm}$ in the entire drainage basin, and average rainfall calculated from the map of isohyets (Daveau 1971b) is $818 \mathrm{~mm}$. However, altitude causes important variations. Below $150 \mathrm{~m}$, precipitation is less than $300 \mathrm{~mm}$. As shown by the plot of the stream-flow at Cidadelhe station over two years of extreme precipitation levels (FIGURE 3), the hydrological regime of the river's discharge is directly controlled by direct runoff induced by the sharp gradients and variation of rainfall in the drainage besin. Today, mainly vines, olive and almond trees are grown in terrace cultivation whose low dry-stone walls ensure that the thin and poor soils are preserved. There is some rearing of sheep and goats.

The differential preservation of the archaeological record

The thin acid soils (Meireles, in Zilhão et al. 1997) and the uneven topography affect the preservation of the archaeological record. Animal and macrobotanical remains are poorly preserved. Some heavily fragmented protohistoric animal bones have been recovered (Carvalho 1999). The schist-based sediments of the Cardina I Gravettian archaeological level have so far only yielded a few burnt bone and teeth fragments. Some very small, poorly preserved charcoal fragments were found in different levels; only three species have been recognized by Isabel Figueiral (pers. comm.): Quercus ilex, Juniperus and Fraxinus, the first two probably intrusive. Tentative AMS and TL. (quarzite) dating of Cardina have indeed shown that the charcoal fragmonts, found in contact

\footnotetext{
* Aubry \& Sampaio, Parque Arqueológico do Vale do Côa, Ministério da Cultura. Avenida Gago Coulinho 19b, 5150 Vila Nova Foz Côa, Portugal). Llach, Seminari d'Estudis i Recerques Prehistòriques, University of Barcelona, Baldiri Reixac s/n, 08028 Barcelona, Spain. Sellami, U.E.R. Dynamique des Milieux et Organisation Spatiale, INA P-G, BP 1, 78850 Grignon, France).
}

Received 14 May 2001, accepted 2 October 2001, revised 3 December 2001 


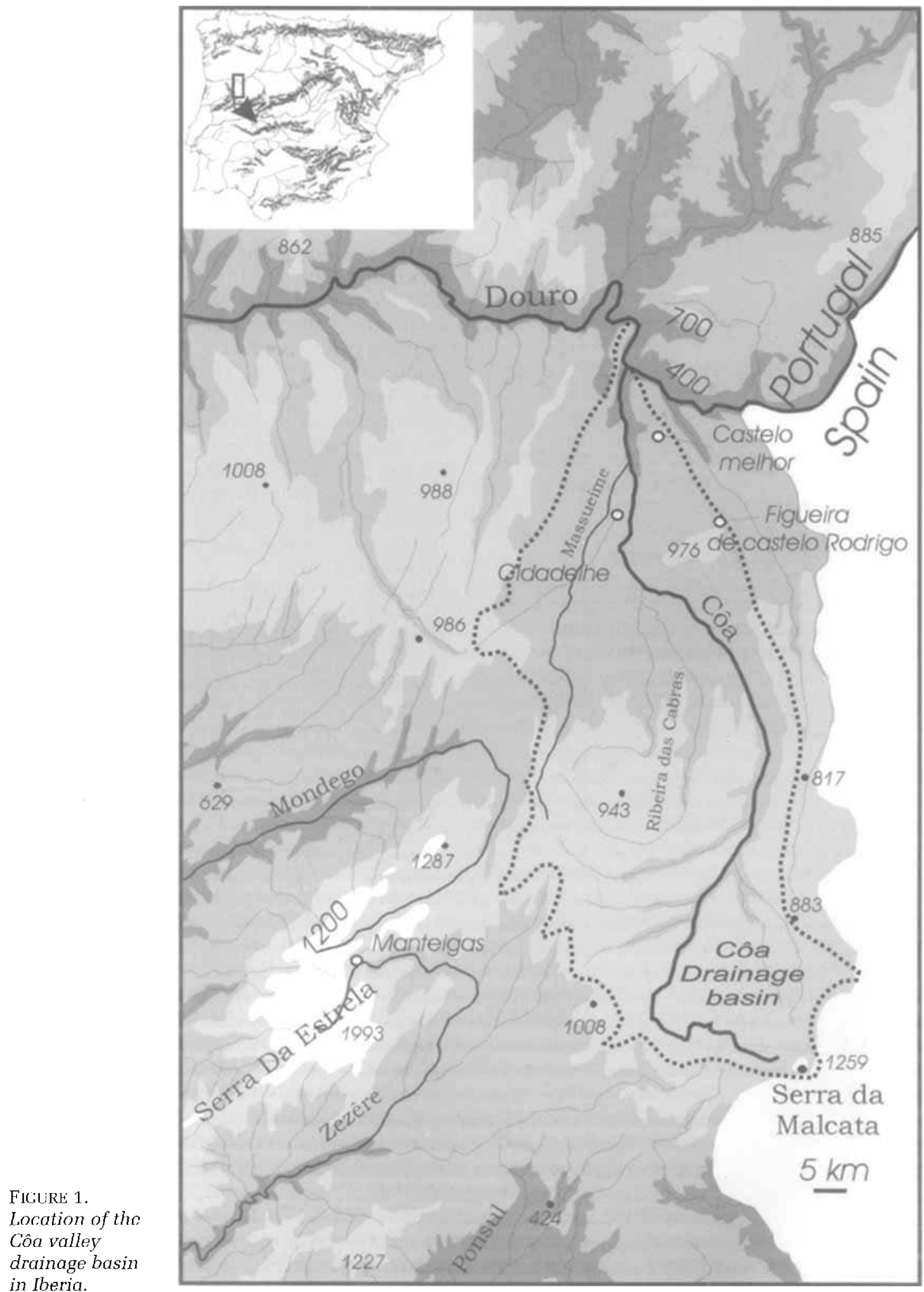



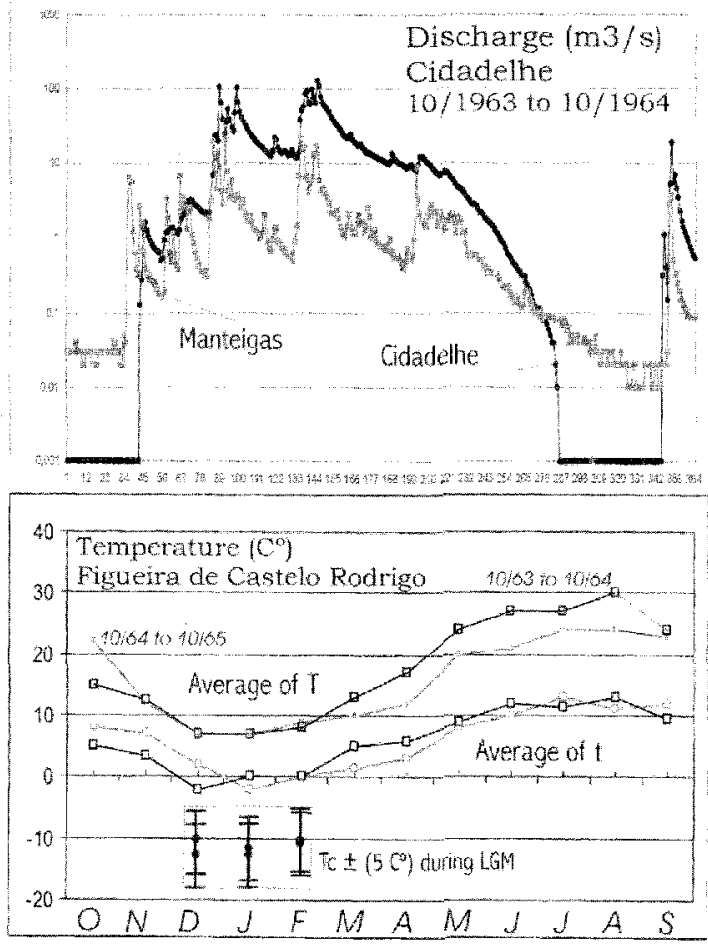

FIGIJRE 2. Reconstruction of climatic coldest month mean temperature; comparison of the discharge in Cidadelhe during two hydrologic years and with the hydrological present-day regime of a drainage basin covered by snow during the winter. with a more clayey layer, derive from soils formed during the Holocene (Mercier et al. 2001). The palaeoenvironment cannot be reconstructed from faunal and plant remains, and larger-scale palaeoclimatic models must be used.

To locate lithics, the surviving evidence of human occupation, we have attempted to define the geomorphological contexts favourable to the accumulation of fine-grained sediments in low-energy transport. In a steep environment, breaks of slope often accumulate weathering debris and transport through surface runoff of the rocks forming the valley walls. In the Côa basin, the older terraces are only very fragmentarily preserved, at $c .35-40 \mathrm{~m}$ above the modern river (FIGURE 4). One site has yielded some poorly diagnostic 'pebble-tools', with the same patina as the coarse terrace gravels. Sedimentologically similar terraces overlain by Eemian (?) red soils at the same elevation along the Douro contain handaxes and cleavers in secondary contexts. An artefactual date before 100,000 agrees with the tentative date of the palaeosols. Lower down, there is a rock terrace, first detected at Cardina I, roughly $20 \mathrm{~m}$ above the modern level of the stream (Zilhão et al. 1995), which corresponds to a deviation of the watercourse caused by the presence of a rhyolite vein. Identical parent rock was identified at lower relative elevations of 6-10 m, at Quinta da Barca and Quinta da Barca Sul (FIGURES $4 \& 5$ ).

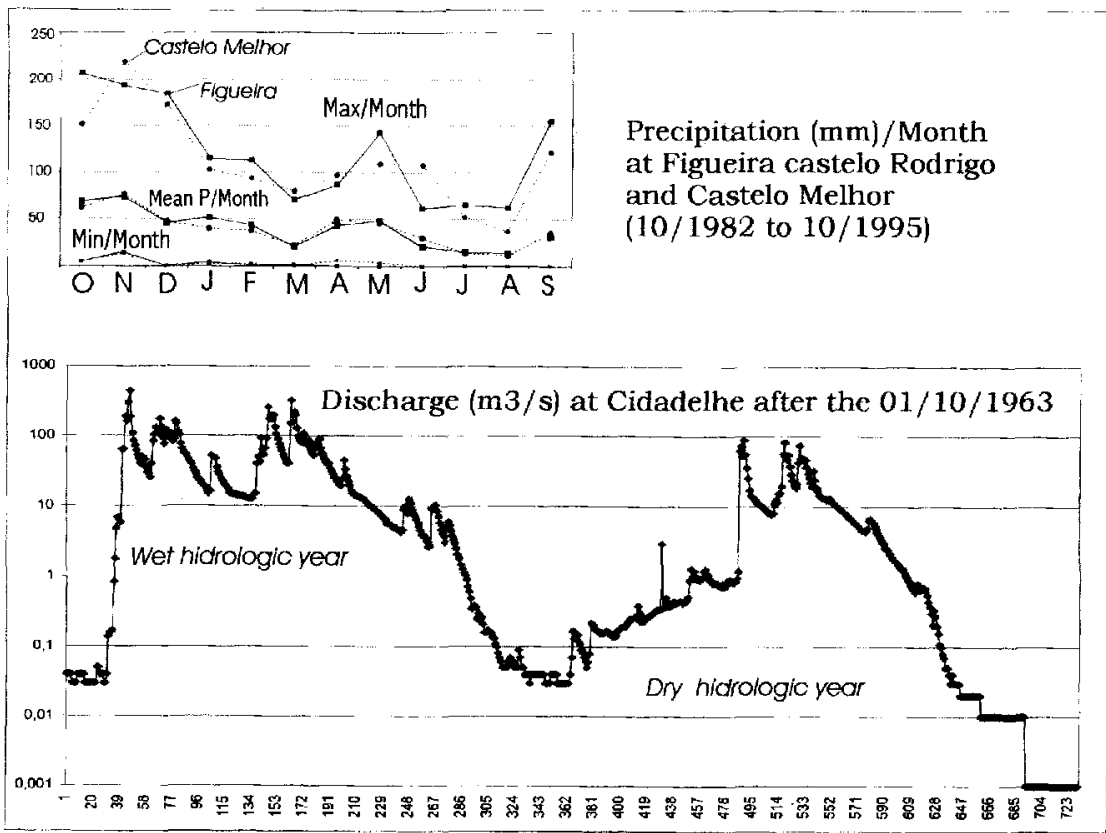

F'IGURE 3. Actual data, monthly precipitation in Vale de Alfonsinho and Figneira de Castelo Rodrigo, precipitation, discharge in Cidadelhe (see FIGURE 2) during two distinct hydrological years. 


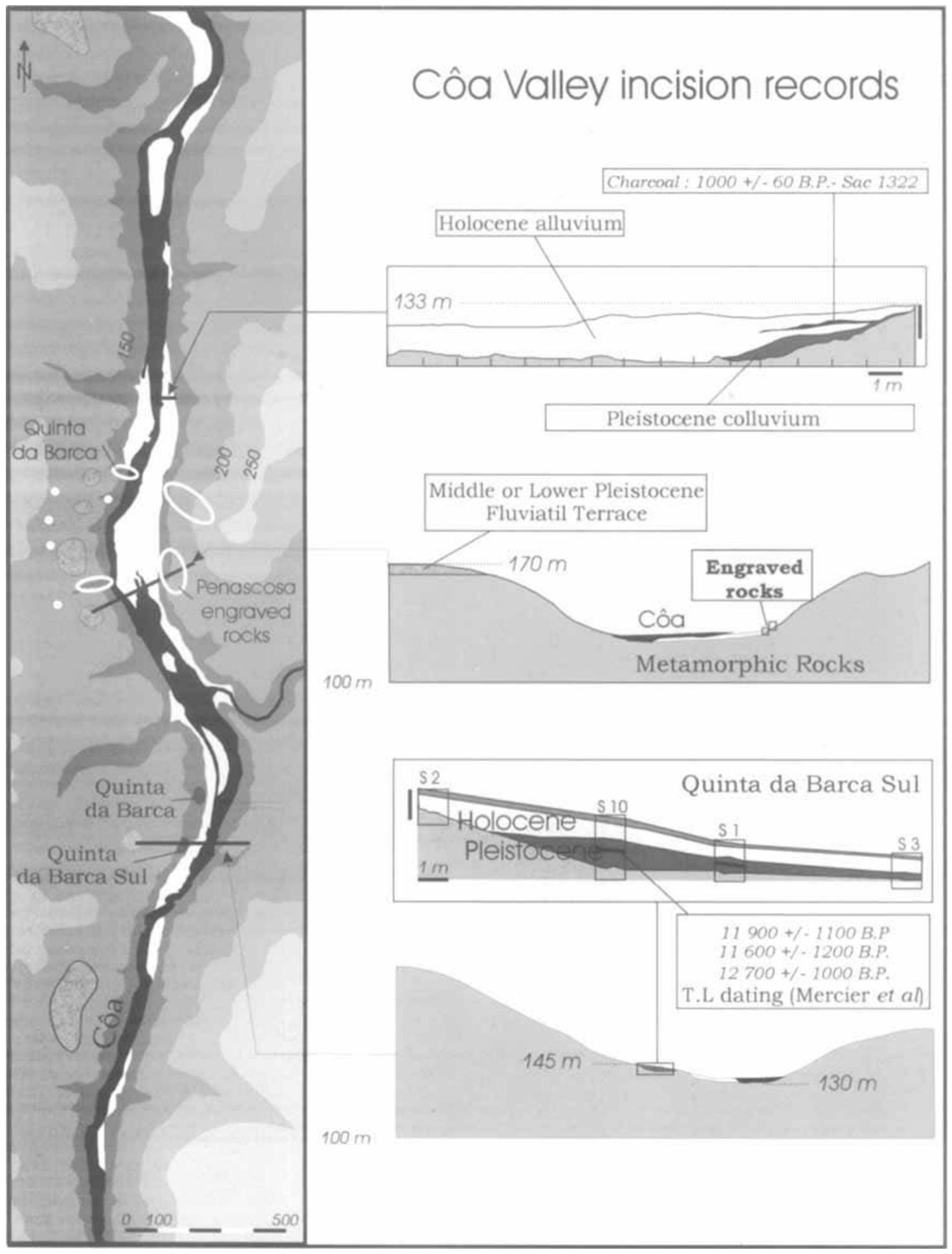

FIGURE 4. Côa valley incision records. 


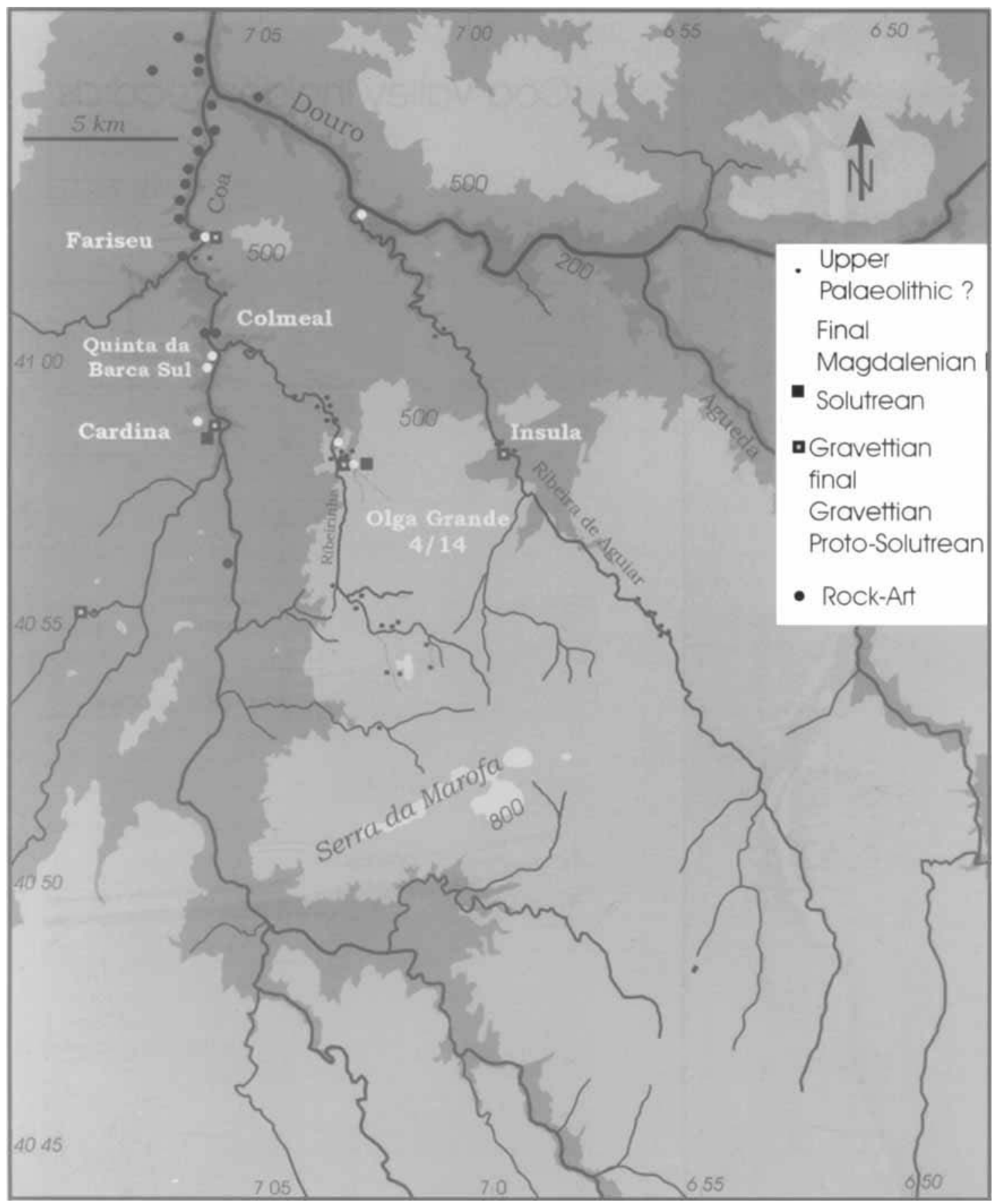

FIGURE 5. Distribution maps of rock art and upper Palaeolithic settlement in the Douro, Ribeira de Aguiar and the Côa Valley.

Surveys on the granitic plateau corresponding to the 500-m high Pliocene planation surface of the Iberian Meseta (Aubry 1998; 2001) also found preserved sediments. The granites drained by the streams that funnel into the Côa have not been so severely incised as in the valley 
bottom, and granitic sands have accumulated on ledges and hollows circumscribed by rock outcroppings and the watercourses where the runoff concentrates. These local geomorphological units are favourable to the preservation of relict soils, and the slope dynamics can be reconstructed. Buried palaeosol horizons have been identified in excavated sites of Olga Grande 4 and 14 (FIGURE 5) which retain diagnostic features of soil devclopment (Sellami 2000).

In 1995, under the supervision of J. Zilhão, several test pits were sunk in the valley bottom alluvial deposits near rocks 4 and 5 of Penascosa (FIgURE 4) (Zilhão 1997a) because the engraved panels were found at the edge of the floodplain. Although there was no archaeological information, much was learnt about the modern valley bottom deposits at the highest floodwater level. All the test pits, as well as a machine-dug trial trench located downstream from the engravings (FIGIJRE 4), have shown an alluvial sequence (Meireles, in Zilhão 1997a; Cordeiro \& Rebelo 1996), dating structurally back to the Pleistocene (Cordeiro \& Rebelo 1996). However, the other data suggest a Holocene age: fragments of ironware, modern pottery, etc. and a date of $1000 \pm 60 \mathrm{BP}$ (Sac 1322) determined on charcoals recovered $50 \mathrm{~cm}$ below the surface of the trench. Two OSL dates confirm the Holocene interpretation; they were from Penascosa alluvial sands, at a depth of $1 \mathrm{~m}$ for the first $(1000 \mathrm{BP})$ and an elevation of $50 \mathrm{~cm}$ above the rock for the second $(4000-6000 \mathrm{BP})$ (Watchman, in Bednarik 1995). At the slopefacing edge of the trench, the characteristics of the lithostratigraphic unit (schist fragments with some rare rolled granite pebbles in a sandy matrix), interpreted as a remnant of Pleistocene colluvium (Zilhão 1997a), point to its deposition prior to an erosional phase (FIGUJRE 4). The gecphysical borehole loggings made in front of Penascosa panels 3,4 and 5 reveal anastomosing channel fills, which correspond to depositional and erosional events, and are similar to those observed in the trench downstream from the engravings (Almeida, in Zilhão 1997a). The deposits were repeatedly eroded during the Holocene.

Following the discovery, $1 \mathrm{~km}$ downstream at the site of Colmeal, of Upper Palaeolithic lithic remains, a test hole was sunk, and discovered an eroded colluvium whose texture and structure were similar to those of the Penascosa
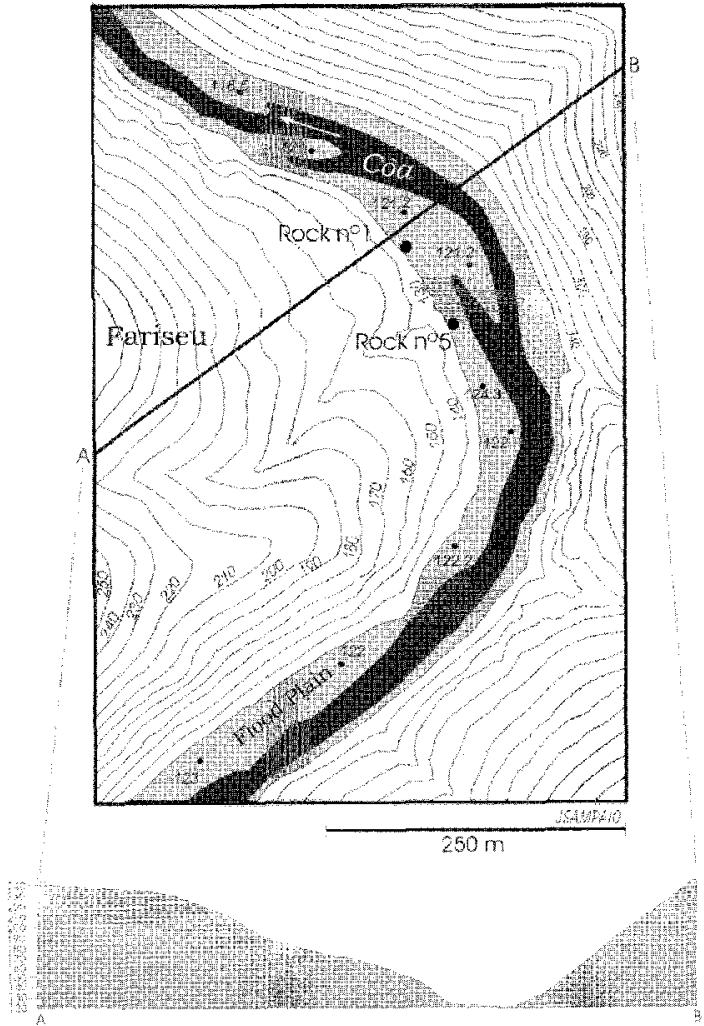

FIGURE 6. Topography of the Fariseu site.

trench. The lithics remains in the residual colluvium suggested that some Pleistocene alluvial sediments might be preserved further downstream. However, the existence of the Pocinho dam built in 1975, controlling the level of the Côa over $7 \mathrm{~km}$, prevented observation of the valley floor.

In December 1999, maintenance work along the Douro enabled survey of the topography of the Côa valley floor. On one of the river banks, several meanders display a morphology conducive to alluvium deposition and preservation (Brown 1997), similar to Colmeal. Tho meander called Fariseu, on the left bank of the Côa some $6 \mathrm{~km}$ from its confluence with the Douro, between the Piscos and Vale de Figueira ensembles, is adjacent to a slope with a gradient of $30 \%$ which rises to $409 \mathrm{~m}$ (FIGURE 6). The different stratigraphic sections (FIGURE 7) show that the uppermost part of the sequence is composed of a silty alluvial deposit ensuing from its inundation ever since the Pocinho dam was erected 15 years ago. Layer 2 is mainly 


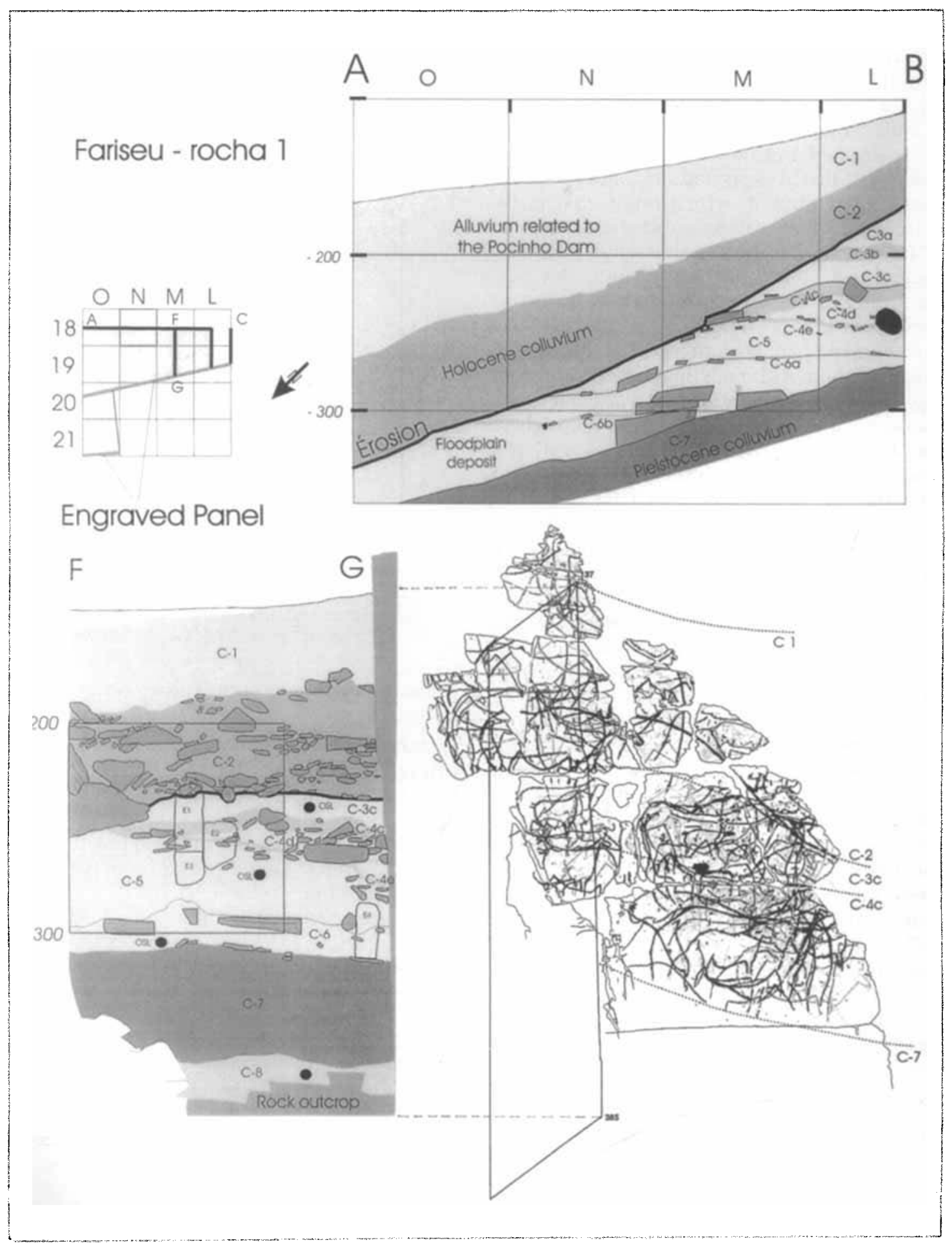

FIGURE 7. Relation between the stratigraphir section and engraved panel 1 of the Fariseu site. 

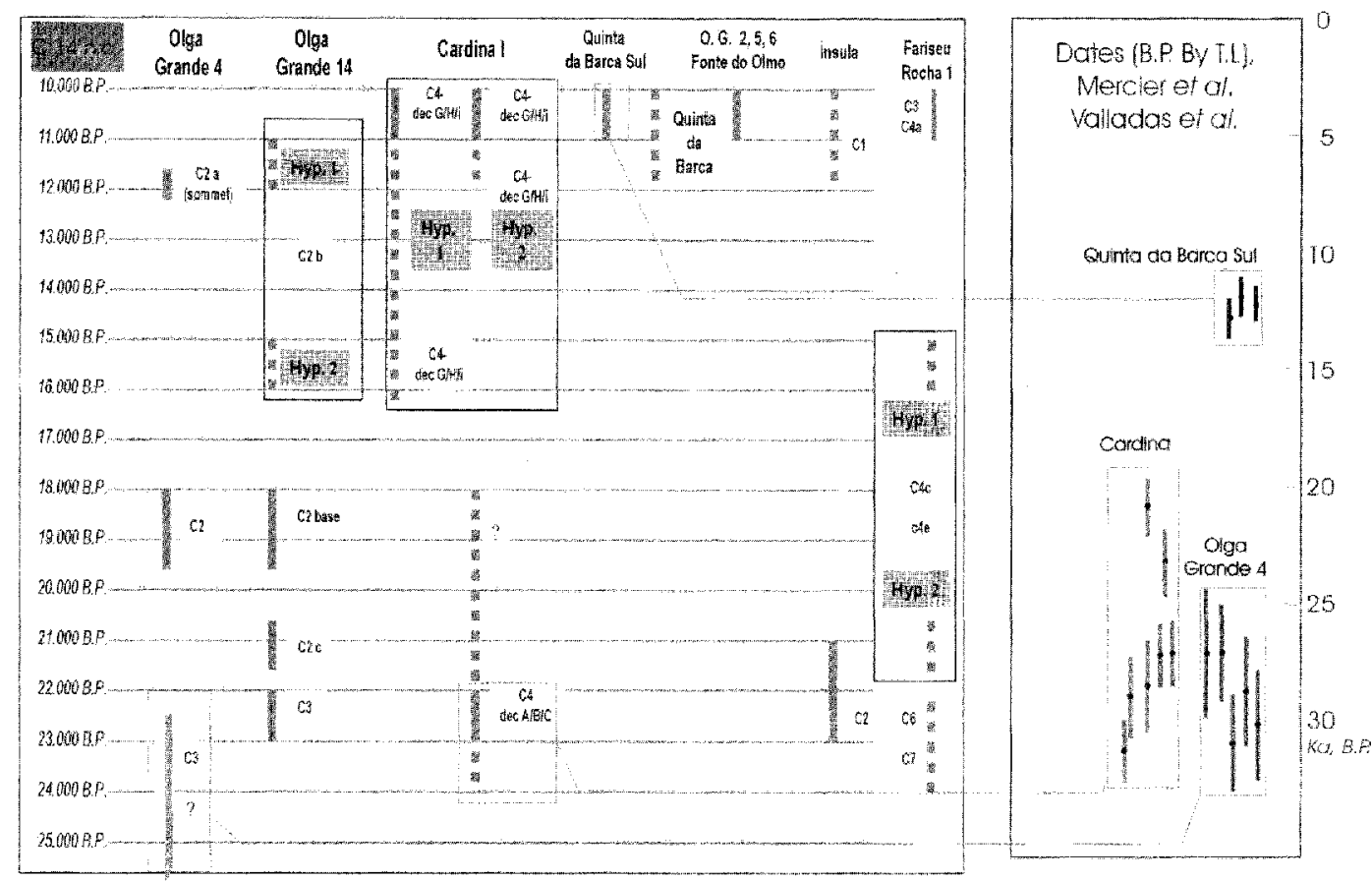

FIGURE 8. Chronology of the Côa valley Upper Palaeolithic sites based on TL dating and lithic industries.

composed of schist flagstones included within a sandy matrix, traces of metal on these schists pointing to a modern age. The dip of the stony beds and of the base of layer 2 indicates that it was deposited after an erosional event whose dip corresponds to that of the slope, and which truncated unit 3 and the underlying units of lower angle dip (FIGURE 7). The difference in dip of the two parts of the sequence, the clayey coaling on the upper face of the slabs of layers $4 \mathrm{c}$ and $4 \mathrm{e}$, and the fact that lithic industries diagnostic of the upper Paleolithic were only found in the levels where slabs are present, argue in favour of a deposition during the Upper Pleistocene for this sequence. The $1 \cdot 5-\mathrm{m}$ thick sequence displays a succession of fine-grained alluvial sediments with a high mica content, deposited during periodic high flows, and probably anthropic accumulations of slabs associated with lithic remains. Their orientation and the fact that pieces could be refitted testify to minimal transportation linked to surface runoff. The arguments concerning the chronological attribution of the different archaeological levels and the correlations established with the other sites in the valley are discussed below.

\section{Human occupation during the Upper Paleolithic: archaeological remains and context}

The chrono-stratigraphic sequence

Application of the above geomorphological model led to the discovery of over 30 sites with lithic; industries that are technologically and typologically attributable to the Upper Palaeolithic (FIGURE 5). Nine of these sites have been tested and four are now in the course of excavation. The establishment of a chrono-stratigraphic sequence of human occupation for the region is based on the stratigraphic sequences of the sites of Cardina I (collaboration with X. Mangado and J.M. Fullola of the S.E.R.P. of the University of Barcclona), Quinta da Barca Sul (collaboration with $\mathrm{X}$. Chauvière of the University of Neuchatel), several loci of Pedras Altas (Olga Grande 4, 13 and 14), and Fariscu (FIGURE 5).). The chronology of these occupations (FIGURE 8) was first defined by diagnostic lithic tools and confirmed by thermoluminescence (TL) dating of fragments of heated siliceous stones found in the different layers of these stratified sites (Valladas et al. 2001; Mercier et al. 2001). 
No lithic assemblage yet found possesses Aurignacian characteristics. Occupation of the region therefore appears to have begun during an early or middle phase of the Gravettian. This is confirmed by the site of Olga Grande 4, where five heated quartzite samples from level 3 , containing micro-gravettes points, have been TL dated to between 26,800 \pm 1800 and 30,000 \pm 2400 $\mathrm{BP}$ (Mercier et al. in press; Valladas et al. 2001). The final Gravettian phase, which is characterized by an abundance of truncated or bi-truncated backed bladelets, has thus far been identified at three sites. Quartzite fragments from the base of level 4 of the site of Cardina have yielded seven dates of which five fall between $26,500 \pm 1800$ and $30,100 \pm 1500 \mathrm{BP}$. The two other dates, which are more recent $(20,700 \pm 1300$ and $23,400 \pm 1500 \mathrm{BP}$ ), probably correspond to ProtoSolutrean and Solutrean occupations attested in the sequence. The Proto-Solutrean, which has been radiocarbon dated to approximately $21,500 \mathrm{BP}$ at sites in central Portugal (Zilhão 1997), is also represented at Olga Grande 14. The Solutrean is attested at sites on the granitic plateau by the presence of Cantabrian-type shouldered points, and in the valley bottom at Cardina I by one fragment of a laurel leaf point (Aubry 1998; 2001). There is a possible early Magdalenian phase at the site of Cardina I. This phase has been radiocarbon dated to approximately $15,000 / 16,000 \mathrm{BP}$ in central Portugal (Zilhão et al. 1997; Zilhão 1997b). The final phase of the Magdalenian is frequently found in the various environmental contexts, at the limit of the floodplain in the level 3 and 4 a of Fariseu, in the valley bottom, preserved colluvial deposits at Cardina I and Quinta da Barca Sul and at numerous sites on the granitic plateau (FIGURE 5). Three samples of heated quartzite, dated by TL, place the occupation of the site of Quinta da Barca Sul at around 12,500 BP (Mercier et al. 2001; Valladas et al. 2001), which is equivalent to the radiocarbon dates of 10,500 BP obtained at sites in contral Portugal (Zilhão 1997b). The lithic industries of this phase are characterized by curved, backed points.

A recent excavation and dating project indicates that the neighbouring region of Freixo de Numão was occupied during the Mesolithic (Monteiro-Rodrigues 2000), refuting the hypothesis that this region and central Iberia were not re-occupied until late in the Early Neolithic (Zilhão et al. 1997; Carvalho 1999). Geological explanations for a lack of preservation of Mesolithic remains in the Côa valley are difficult to imagine, since we must accept that all occupations of this phase were located on the floodplain of the Côa river. However, some undiagnostic lithics recovered during the survey of the granitic plateau may be of this date.

\section{The engraved representations}

The Palaeolithic engraved art of the Côa Valley currently comprises 24 groupings within an ensemble of 164 rocks (Baptista 2001; FIGURE 5), scattered over the last $17 \mathrm{~km}$ of the river and its tributaries, near its confluence with the Douro.

The art of the Côa Valley is part of a regional group that includes the sites of Mazouco, 40 $\mathrm{km}$ to the northeast and upstream from the Douro, Ribeira da Sardinha noar the mouth of the Sabor, Sampaio, Pousadouro and Fraga Escrevida upstream on the same river, a right bank tributary of the Douro, and Siega Verde, on the left bank of the Agueda River. In addition, it is said that many other engravings may be submerged in the Douro river basin, under reservoirs.

The engravings are on naturally flat surfaces, slickensides in metamorphic rocks, smoothed during the movement of two masses of rock. These vertical fracture surfaces were progressively exposed by traction and tilting during the process of incision by the river system. The siliceous and metallic films that cover these surfaces are the result of a complex evolution. They are subject to a constant process of redeposition, which is the source of the patina on the engraved lines. Fragments of organic materials contained within these films were subject to direct dating (Phillips et al. 1997). The results prosented by Dorn (1997) confirm Zilhão's ideas (1995), and indicate that the films covering the panels do not constitute a stable system that is continuously contaminated by colonization, even before their exposure by micro-organisms and subject to local and not only time/dependent weathering (Pope 2000). The dates obtained by the AMS method on micro-fragments of organic materials (Watchman 1996) and by micro-erosion (Bednarik 1995) thus provide, al best, only minimum ages.

Diverse engraving techniques were employed (Baptista \& Varela Gomes 1995; 1997; Baptista 1999a: 1999b; 2001) which include fine inci- 


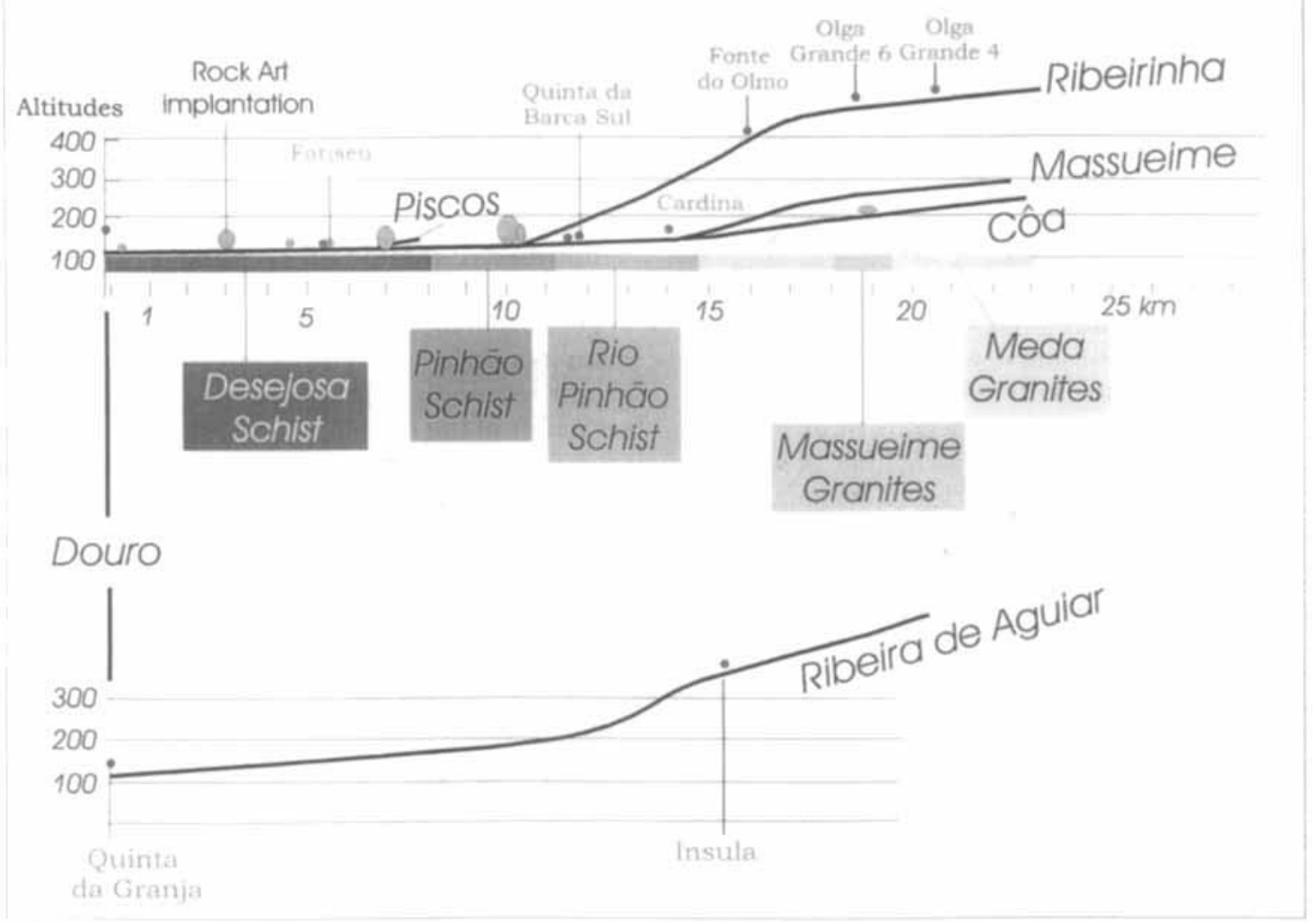

FIGURE 9. Preservation of rock art and habitat as a function of geology.

sions, direct or indirect pecking, deep U or Vshaped incisions, and more rarely, scraping. The deep incisions are often proceded by pecking. The only examples of an association of engraving and painting are preserved in the Faia rock shelter, which is within the group of engravings located furthest upstream (FIGURE 5).

This ensemble is the only one preserved on granites, which are of a particular petrographic variety. These data, along with the distribution of the engraved panels (FIGIJRE 9), show clear corrclations with the limits of different geological formations. An analysis of the differential preservation of engravings at different positions on the valley slopes is still in progress as part of a study of the site of Quinta da Barca Sul and the ensemble of engravings at Quinta da Barca (Callame et al. 2000).

\section{Chronology of the engravings}

The dating of engravings on stone surfaces in the open air or caves is problematical. Firstly, stylistic comparisons were made with parietal and portable representations that have been objectively dated (Zilhão 1995; Baptista 1999a; 2001; Sacchi 2000; Guy 2000). Other, more precise relations have since been identified, and the engravings have been associated with other categories of remains. Due to its favourable geomorphological location (FIGURE 6), a testpit dug in 1999, opposite rock no. 1 of the site of Fariseu, has permitted the establishment of a stratigraphic relationship between a vertical engraved panel and floodplain deposits (FIGURE 7), interbedded with different Upper Palaeolithic levels (Aubry \& Baptista 2000; Aubry in press; Aubry \& Garcia Diez 2001). Dating of burnt quartzite pebbles from the different archaeological levels is currently in progress, by H. Valladas and N. Mercier. Howevor, the lithic industries contained in them are technologically and typologically similar to the locally dated Upper Palacolithic romains. $\Lambda$ chronology has been proposed (IIGURE 8). The stratigraphic relationship with the vertical panel indicates that many of the 82 ongrav- 
ings relate to the older archaeological occupation on the top of level 7 , and covered by final Magdalenian level 3, and $4 \mathrm{c}$ and $4 \mathrm{e}$ attributed by lithics to Early Magdalenian or Protosolutrean. Two quartzite picks associated with level 3 of the site of Olga Grande 4 already suggested that the production of the engravings began during a Gravettian phase in the region (Aubry 2001; in press). A functional analysis by $\mathrm{H}$. Plisson of these picks, discovered in a granitic site, showed that they could have served in the pecking of schist surfaces, a kind of rock only found a few kilomotres distant.

A long, chronologically continuous artistic sequence has been proposed (Zilhão et al. 1997; Baptista 1999b; 2001), and is confirmed, in part, by two engraved schist cobbles found in levels $4 a$ and $4 \mathrm{e}$ of the top of the Fariseu sequence. Analysis by M. Garcia Diez (Garcia Diez \& Aubry in press) of the two faces of the cobble from levol 4a, which contains a lithic industry characterized by a curved backed points similar to the points recovered in the Quinta da Barca Sul occupation dated to around $12,500 \mathrm{BP}$ by TL, revealed zoomorphic representations with a geometric tendency, traced by multiple incisions. Figures with the same morpho-technical characteristics have been found in the ensembles of engravings located along the Côa and left bank tributaries of the Douro (Garcia Diez \& Aubry in press). The engraved schist cobbles of level $4 \mathrm{e}$ reveal non-figurative traces associated with an ibex representation that has stylistic parallels with the portable representations of the Parpalló cave (Gandia, Spain).

\section{Climatic reconstruction and related changes in the hydrological regime}

The available data for the last Glacial Maximum reconstructed from marine core isotopic: measurements (Bond et al. 1993), ice-coro records (Johnsen et al. 1992; Taylor 1999) and pollen data (Peyron et al. 1998) indicate that the annual temperature mean was lower by $10 \pm 5^{\circ}$, and the mean temperature of the coldest months were lower by $15 \pm 5^{\circ}$. Estimated precipitation levels are approximately $30-50 \%$ lower, evaluated at $300 \mathrm{~mm}$ for southern Europe. The data available for the period between 40,000 to $10,000 \mathrm{BP}$, corresponding to the Upper Palaeolithic, shows a cold and dry Heinrich event, in a general dry and cold context (d'Errico et al. in press).
Zilhão (1997b) has proposed a palaeo-environmental reconstruction for Portugal based on deep sea core data, the Serra de Estrela mountain range glacial deposits (Central Portugal), pollen sequences of mountain lakes and faunal and macroscopic plant remains from archaeological sites. According to the schema proposed, altitudes lower than $700 \mathrm{~m}$ would have had 'compressed' (Mateus \& Queiroz 1993) zones of alpine, sub-alpine, boreal and temperate vegetation. Altitudes above $700 \mathrm{~m}$ would have been occupied by continental steppe. The geomorphological characteristics of the highest reliefs of the Estrela Mountains indicate that they were covered by glaciers of a maximum extension of approximately $70 \mathrm{sq} . \mathrm{km}$, consistently solid at $1600 \mathrm{~m}$ altitude (Daveau $1971 \mathrm{~b}$; Ferreira 1993). The geomorphological study makes it possible to reconstruct a broad annual range and strong western winds during winter. Analyses of oceanic sediments taken off the coasl of Portugal have permitted the identification of a cold phase between 11,000 and 10,000 $B P$, confirmed by recent analysis of ice cores from Greenland and the Antarctic (Taylor 1999) which demonstrate a rapid warming within a few decades, with means increasing by around $10^{\circ} \mathrm{C}$, following the cold phase of the Late Dryas.

If we apply the Last Glacial phase models to data collected in the Côa valley stations, the temperature of the coldest month (Tc) was lower than $0^{\circ}$ between December and March (FIGURE 2). During this period, the precipitation, as snowfall, was accumulated in the form of snow cover and the discharge was essentially influenced by underground flow. In a drainage basin covered by snow during the winter (FIGURE 2) the discharge during the year was different, since high flows were caused by spring rainfall and increased April-May temperatures applied to the snow cover (Ribeiro et al. 1994). This reconstruction shows that the Côa probably did not have a typical snow and ice alimentation hydrological regime with a normal peak of distribution of discharge during the spring; more probably the Côa regime and that of related tributaries would have been intermediate and, as suggested by Zihão (Zilhão et al. 1997), more regular during the course of the year. In this reconstruction, the highest water levels could correspond to a warm spring when increased temperature acted on the snow cover accumulated during winter over a large area of 
the river, leading to the highest discharge when the bottom of the valley was probably unoccupied.

In the absence of macrobotanical remains, environmental reconstruction is based on micromorphological analyses of Upper Pleistocene deposits. This type of analysis has thus far been conducted for the sedimentary sequences of the two granite based sites of Olga Grande 4 and 14 (Sellami 2000). The sites of Farisen (F. Sollami) and Cardina I (M. Bergada, University of Barcelona) are under analysis. The former is located at the limit of the floodplain, and the latter in an accumulation of fine colluvial sediments transported by diffused runoff.

Micromorphological analysis of the site of Olga Grande 14 (Sellami 2000) has revealed Gravettian hydromorphic features. These are interpreted as related to the accumulation of water in depressions from melted snow and frozen ground. These data, set within the global climatic reconstruction, could explain the density of occupation on the granitic plateau, al altitudes above $450 \mathrm{~m}$ (FIGURE 5 ). The seasonal accumulation of water in depressions, with lower than modern precipitation, could have played an important role in local herbivore movement. Moreover, the presence of snow cover attested above $550 \mathrm{~m}$ could be used as a basis for reconstruction of the Côa river system, based on the sequence of the site of Fariseu. With TL and OIS datings, the levels of fine sedimentary deposits on the alluvial plain edge could date the highest wator level phases.

Observation of the climatic chronology (FIGURE 8) reveals a correlation between cold and dry phases and high occupation densities in the region, as in central Portugal. It could be explained by conditions that are favourable to fine colluvial deposits and differential preservation of remains (Zilhão 1997b). Howevor, any environmental factors related to the changes of the hydrological regime and of faunal resources during the year must also be considered.

\section{Reconstruction of the modes of resource exploitation in the territories}

Lithic resourcos of the Côa basin sites are being studied (Aubry et al. in press), by systematic regional surveys and comparisons with archaeological materials. The raw materials not identified through survey are subject to petrographic thin-section analyses, which then di- rect new surveys.

The Upper Palaeolithic lithic industries are primarily made on quartzite, quartz and, to a lesser degree, rock crystal. The use and displacement of quartz and quartzite in Gravettian sites has been described near the flint sources of the Rio Maior region (Zilhão 1997; Thacker 2000). In all cases, these three categories constitute nearly $99 \%$ of the weight of the lithic assemblages. The two principal raw materials are local and were transported a few kilometres. The rock crystal is of local origin in the Late Glacial assemblages, and was transported from the mouth of the Sabor valley, at least $25 \mathrm{~km}$ to the north, during the Gravettian. Other categories of hydrothermal silicifications, detected during surveys and absent in the alluviums of Côa, come from a maximum range of $50 \mathrm{~km}$ in the Côa and other parallel river basins.

The different types of flint possess petrographic and palaeontological characteristics that indicate a siliceous epigenesis of carbonaceous sediments that cannot be found in the region (Aubry et al, in press). The systemalic surveys carried out based on these data indicate several geological sources and regional origins. While this evidence demonstrates human movement over approximately 50,000 sq. $\mathrm{km}$, the precise nature remains to be defined. The first hypothosis of flint expeditions is not supported by the geographical diversity of sources (FIGURE 10). Two other different systems of resource cxploitation can be proposed; in the first, the Côa basin would have been sporadically frequented by several human groups originating from a region in which flint resources are located; in the second, a local group would have been joined by others at seasonal aggregation sites, or exchanged raw materials (FIGURE 10).

The exploitation of lithic resources of mediocre quality, originating from a distance of less than $50 \mathrm{~km}$ (black rock crystal, G-10, G-14 and G-15, FIGURE 10), al all sites during all phases of the Upper Palaeolithic, suggests the presence of a group that exploited a territory of approximately 500-2000 sq. km. The exploitation of territories of this size has already been attosted by flint material distribution in central Portugal (Zilhão 1997b). Moreover, the association of different types of flint at granilic plateau sites, in a low density, which we interpret as short-term, logistical occupations related to the seasonal presence of water, more strongly 


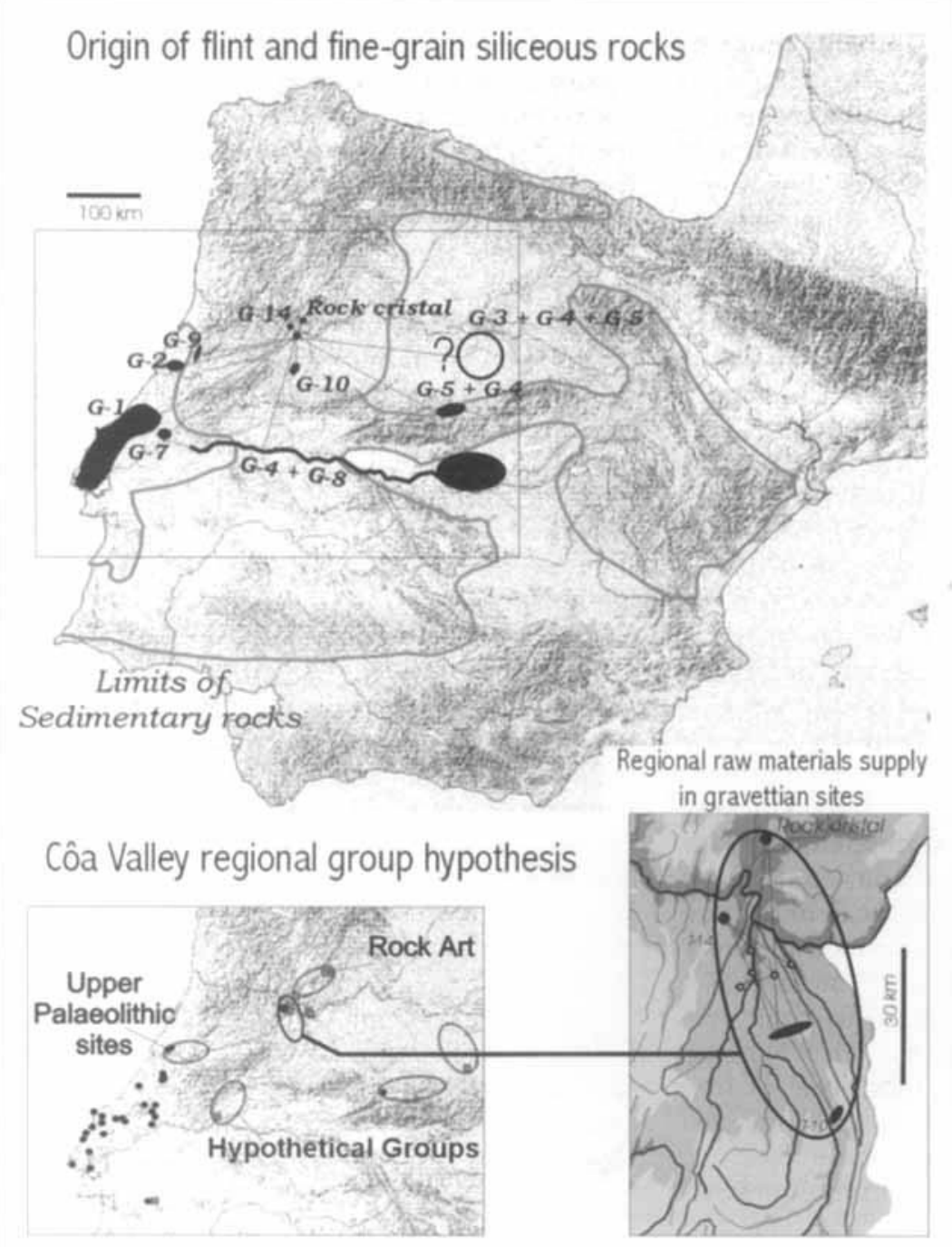

FIGURE 10. Flint and fine-grain siliceous rocks discarded in the Gravettion sites of the Côa Valley and hypothesis of territories exploited by regional groups during the Upper Palaeolithic. supports the second hypothesis and suggests the existence of associated residential sites. We have not yet analysed the exploitation of regional resources through the spatial distribution of sites in different ecological contexts, considering the factors influencing artefact preservation, intra-site spatial analysis, characterization of local movements of raw materials and the variability of abandoned lithic tools.

Throughout all of the Upper Palaeolithic, there are clear differences in the occupation of valley and plateau. For example, during the Gravettian, sites are distributed throughout different environments (FIGURE 5). Lithic assemblages on the plateau are associated with large (1x1.5 m) accumulations of cobbles or fragments of heated quart $z$ and quartzite. The origins of regional raw materials during this phase (FIGURE 10) show movements along the Côa and between the valley bottom and the plateau, where the density of lithic assemblages, the high proportion of microlithic projectile points and their discard after utilization, indicate specialized hunting camps. Conversely, the final Gravettian level of Cardina I, along the valleybottom, is a dense circular deposit, c. $4 \mathrm{~m}$ in diameter, of heated quartz, rhiolite, granite and quartzite pebbles, particularly placed in $30-\mathrm{cm}$ decp holes. One of these is bordered by slabs and containing numerous charcoal micro-fragments. 
These data suggested a frequent re-occupation of the same spatially delimited area, interpreted as a hut. The heated materials are associated with retouched tools essentially composed of quartz scrapers and broken backed bladelets.

\section{Discussion}

Allowing for preservation factors, the distribution of sites and lithic raw materials indicates the exploitation of territories on a local and regional scalo, and of regions up to $200 \mathrm{~km}$ away. While several arguments seem to favour the hypothesis of a regional group exploiting a territory of a spatial range of about $50 \mathrm{~km}$ (Aubry et al. in press), at least during the final Gravettian and final Magdalenian phases, the full pattern remains to be precisely defined.

In the Ocreza basin, a tributary on the right bank of the Tagus valley, along the Sabor, a tributary on the right bank of the Douro, the recent discovery of stylistically similar engravings indicates, as attested by flint remains, a largescale social network extending over the central Iberian Cordillera. This network probably rogularly exploited territories of less than 1000 $\mathrm{sq} . \mathrm{km}$.

The preserved engravings show a clear geological limit, but the geologically caused preservation of fracture surfaces cannot alone explain the preferential location of engraved panels with numerous superimposed, pecked motifs at the limit of the Côa floodplain. These principal ensembles of engravings are found on the right bank of the watercourse where, due to tectonic activity, the panels produced by the destabilization of blocks face south and accumulate heat during the day.

The discovery of an engraved panel covered by occupation layers at Fariseu, and picks in a Gravettian layer (layer 3) at Olga Grande 4, allow us to attribute some of the pecked engrav-

\section{References}

Alnbry, T. 19y8. Olga Grande 4: uma sequência do Paleolítico superior no planal to entre o Rio Côa e a Ribeira de Aguiar. Revisla Porluguesu de Arqueología 1(1): 5-26.

2001. L'accupalion de la basse vallée du Côa pendant le Palćolithique supérieur, in Zilhão et al. (ed.): 253-73.

In press. Le contexte archéologique de l'art paléolithiquc à l'air libre de la vallée du Côa, in Actes du colloquo L'art Paléolithique à l'air libre. Le Paysage modifić par l'image. Tautavol-Campôme, 7-9 octobre 1999. Perpignan: Presse Universitaire de Perpignan.

AUERY, T. \& A.M. BAPTISTA. 2000. Une datation ubjeclive de l'art du Côa, La Recherche, Hors-série no. 4, Novembre 2000, La naissance de l'art: 54-5. ings with similar morpho-technical characteristics to a phase of Solutrean or Gravettian. At Fariseu, the top of Layer 7 is associated with the base of the engravings of the panel 1 at this site. The density and type of lithic materials found in this layer do not indicate a long-term occupation of this part of the site. Nonetheless, the covering of the entire available surfaco with supcrimposed lines, and the recurrent geomorphological location on meanders of this type of representation, in association with less rich panels higher on the slopes and visible from these locations, suggest an association with undated and defined human occupation activiLies on floodplain erosional deposits. Meanwhile, we must be cautious in goneralizing from this interpretation of panels with numerous superimposed, pecked motifs to the full ensemble of Palaeolithic engravings of the Côa valley, and in particular to the small, incised motifs whose spatial distribution is distinct.

The ancient seasonal hydrological regime of water reserves and flow appears to be very different from the present day, as a result of winter snow cover. This model, independently confirmed by the first micromorphological study of granitic sitc deposits above $500 \mathrm{~m}$, affects the availability and exploitation of resources in the Côa Valley and Iberia itself during the last glacial period,

More data on the preservation of different categories of remains, absolute dating, micromorphology, the activities behind lithic assemblages and a better definition of the exploited territories will improve our interpretation of the open-air symbolic representations in the Upper Palaeolithic.

Acknowledgements. We thank Paul Bahn, João Zilhão and the two amonymous referess for their stimulating and critical reading of the manuscript.

АIJBKY, T. \& M. GAKcí Diez. 2001. Actualiłé sur la chronologie el l'inlerprétation de l'art de la vallée du Côa, Les Nouvelles de I'Archólogic 82: 52-7.

AuBry, 'I', X. MANGADO, J.M. FuLLOLA, L. ROSELL \& J.D. SAMPaiO. In press. Raw material procurement in the upper Paleolithic settlements of the Cóa Valley (Portugal). Now data conrerning modes of resources exploitation in Iberia. Abstract, bth annual meeting of the E.A.A., 10-17 September 2000, Lisbon

Baptista, $\Lambda$. M. 1999a. No tempo sem tempo. A arte dos caçadores paleolitico do Vale do Côa, Centro Nacional de Arte Rupestre, Vila Nova de Foz Côa: Parque Arqueológico do Côna. 
1999b. O cirlo artístico quaternário do Vale do Côa. Com algumas considerações sobre estílns, valoração estética e crono-estratigrafia figurativa. Arkeos, perspectivas em diálogo (A.R. Cruz \& L. Ousterbeek (coord.), $1^{0}$ Curso Intensiva de Arle Pró-Histórica Luropeia, Tomo II) 6: 197277

2001. 'The Quaternary Rock Art of the Côa Valley (Portugall), in ZILILÃO ET AL. ( $\left.\mathrm{E}^{\prime}\right]$ ).): 237-52.

BAPTISTA, A.M. \& M. GOMFS. 1995. Arte rupestre do Vale do Cồ 1. Canada do In ferno. Primoirus impressões, Trabalhos de Antropologia e Ltnologia 35(4): 349-422.

1997. Arte Rupestre, in Zilhão (1997a): 213-406.

BriJNAK|K, R. 1995. The Côa petroglyphs: an obituary to the stylistic dating of Palaeolithic rock-art, Anliquity 69: 877 82

BOND, G., W. BROHCKt:R, S. JOHNSEN, J. MCMANUS, L. LABEYRIES, J. JOIJZEL \& G. BONANI. 1993. Correlation between climate records froni North Atiantici sediments and Greenland ice, Nature $365: 143-7$.

BROWN, A.G. 1997. Alhuvial geoarchaeology: floodplain archaeology and environmental change. Cambridgo: Cámbridge University Press.

Calame, A. F.X. Chauvière, I. Decilanez \& S. Tymitt.A. 2000. Lo projet Quinta da Barca Sul. Interventions archéologique 2000. Rapport d'activité, I.P.A.

CAKVAl.HO, A. 1999. Os sítios de Quebradas e de Quinta da Torrinka (Vila Nova de Foz Côa) e o Neolítico antigo do Baixo Côa, Revista Portuguesa de Arqueologia, 2(1) 1999: 39-70.

Cordeiro, A.M. \& F. Rebelo, 1996. Carta geomorfológica do Vale do Côa a jusante de Cidadelhe, Cadernos de Geografia 15: 11-33. Coimbra F.L.U.C. ,

DNVEAL, S. 1971a. La glaciation de la Serra de Estrela. Finisterra, Revista Portuguesa de Geografia VI: 11. Lisbon.

1971b. Memório do Centro de Fstudos Geográficos, n”-3. Lisboa.

D'Errico, F., M. Vanharirin, M. F. SanchIz Gosi, F. Grousset, H. VALLADAS \& I.P. RIGAIID. 2001. Los possibles relations entre l'art des cavernes et la variabilité climatique rapide do la dernière période glaciaire, in J.-N. Barrandon, P. Gibert \& V. Michel (ed.), Actes du Colloque 'Datations $X X I^{"}$ Rencontres Internationales d'Archéologie et d'Histoine d'Antibes' 19-21 octobre 2000: 333-47. Antibes: Edilion APDCA.

DorN, R. T. 1997. Constraining the age of the Côa valley (Portugal) engraving with radiocarbon dating, Antiquity 71 : 105-15.

FLrReira, A.B. 1993. Manifestações geomorfológicas glaciares e periglaciares em Portugal, in O Quaternário em Portugal, balanco e perspectivas: 75-84. Lisbon: Colibri.

f'erreira DA Silva, A. \& M.-L. Ribiriro. 1991. Carta geológica de Portugal. Notíria explicativa da folha 15-A, Vila Nova de Foz Côa, Lisbua, Serviçus Geológicos de Portugal.

García Diez, M. \& T. Aubry. In press. Grafismo mueble en el Valle de Côa (Vila Nova de Foz Côa, Portugal): la estación arqueológica de Fariseu. Zephyrus.

GuY, E. 2000. Des éroles artistiques au Paléolithique?, La Recherche, Hors-série 4, Novembre 2000: 60-61.

JOHNSEN, S.J., H.B. CLIUSEN, W. DANSGAARD, K. I'LTHRER, N. Glndestrup, C.U. Hammer, P. Iversen, J. Jouzel, B. STAUFFER \& J.P. STEFFENSEN, 1992. Irregular glacial interstadials in a new Greenland ice core, Nature, 359 311-13.

L.AMBERT, R. 1996. Géographie du cycle de l'eau. Amphi7 Géngraphie. Touluuse: Presses Iniversitaire du Mirail.

MATriss. J.E. \& P.F. Quliko\%. 1993. Os estudos de vegetação quaterrária crm Portugal; contextos, balanços de resultados, perspectivas, in $O$ Quatornário om Portugal, balanco o perspectivas: $105-31$. Lisbon: Colibri.

Mercier, N., H. Valladas, L. Froget, J.-L. Jorons, J.-L.Reyss \& T. Avbry. 2001. Application de la méthode de la thermoluminescence à la datation des occupations paléolithiques de la vallée du Côa, IN ZnHÃo ET AL. (ED.) $275-80$.

Monteiro-Runkugues, S. 2000. A estaçăo neolítica do Prazo (Freixo do Numäo - Norte de Portugal) no contexlo do Neolítico antigo do noroeste peninsular. Algumas consideraçóes preliminares, Actas do $3^{4}$ Congrcsso do Arqueologia Peninsular, Vila real, 22-26 de Setembro de 1999, Vol III. Purlo: ADECAP.

Peyron, O., J. GuloT, R. Chednadi, P. Tarasov, M. Reilee, I.L. IE Balleieit, 5. Bottema \& V. Andreet. 1998. Climatio reconstruction in Europe for 18,000 yr he from pollen data, Quaternary Research 49: 183-96.

PHILLIPS, F.M., F, MONTGOMLRY, D. ELMORE \& P. SHARMA. 1997 Maximun ages of the Côa valley (Portugal) engravings measured with Chlorine-36. Antiquity 71: 100-104.

Pope, G.A. 2000. Weathering of petroglyphs: direct assessment and implicutions for dating methods, Antiquity 74: 83343.

RiBeiro, O., H. LaUtensach \& S. Daveau. 1994. Geografía de Portugal. Vol. II. O Ritmo Climático e a paisagem. 2nd edition. Lisbon: Ediçôes João Sá da Costa.

SACcin, D. 2000. The impact of recenl discoveries on our knowledge of rock art of the European Palaeolithic. The Review of Archacology 21(1): 8-15.

Sellami, F. 1999. Reconstitution de la dynamique des sols des terrasses de la Dordogne à Creysse (bergeracois). Impact sur la conservation des sites archéologiques do plein air. Thèse de doctorat, INA-Paris-Grignon.

2000. Depositional and post-depositional soil evolution and the inferred environmental conditions of open Paleolithic sites at Côa Valley in Portugal. Abstrac:I. EAA filt An nual Meeting, Lisbon, 10-17 September 2000.

TAYLOR, K. 1999. Rapid climate change, Americon Scientis 87 $320-27$.

THACKen, P.T. 2000. The relevance of regional analysis for Upper Paleolithic archaeology: A case study from Portugal, in G.L. Peterkin \& 11.A. Price [cd.], Regional approaches to adaptation in late Pleistocene western Europe: 25-45. Oxford: Archaeopress. British Archaeological Reports International series $S 896$.

VALLADAS, H., N. MHKCIIK, L. FROGET, J.L. JORONS, J.T. RHYSS \& T. Aчвку. 2001. TL dating of Upper Palpolithir Siles in the Côa Valley (Portugal), Quatemary Seience Reviews 20: $939-43$

WATCHMAN, A. 1996. A review of the theory and assumptions in the AMs' dating of the Foz Côa petroglyphs, Portugal Rock Art Research 13(1): 21-30.

ZıLHÃO, J. 1995. The age of the Côa valley (Portugal) rock-art: validation of archaenlogical dating to the P'alaeolithic and refutation of 'scientific' dating to historic or protu-historic times, Antiquity 69: 883-901.

(Coord.) 1997a. Arte Rupestre e Pré-História do Vale do Côa. Trabahos de 1995. 1996. Relatório Científico an Governo da República uortuguesa elaborado nos termos da resolucão do Conselho de Ministros $n^{0} 4 / 96$, de 17 de Janeiro. Lisbon: Ministério da Cultura.

1997b. O Paleolítico superior da Estremadura Portuguesa. Lisbon: Colitri.

Zilhó, J., T. Aubry \& A. Cakval ho (ed.). 2001. Actes du Colloque 'Les premicrs hommes modemes de la Péninsule lhérique' Vila Nova de Fuz Côa, 22-24/10/1998, Trabalhos de Arqueologia 17. Lisbon.

ZILHÄO, J., T. AUBRY, A.I: CARVALHO, A.M. BAPTISTA, M.V. GOMES \& J. MEIRELES. 1997. The rock art of the Cô vallev (Portugal) and its archaeological context: first results of current research, Journal of European Archatology $5 /$ 1: $7-49$

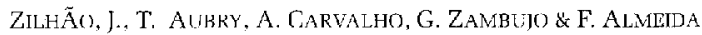
1995. O sítio arqueológico paleolítico do Salto do Bo: (Cardina, Santa Comba, Vila Nova de Foz Côa). in Actas do $\mathrm{I}^{\mathrm{a}}$ Congresso de Arqueologia Peninsular: Trabalhos de Antropologia e Linologia 35(4). 